\title{
Current Studies of Treating Processes for Nickel Laterite Ores
}

\author{
Xiaoping Wang a ${ }^{a}$ Tichang Sun ${ }^{b}$, Chao Chen ${ }^{c}$ and Tianyang $\mathrm{Hu}{ }^{d}$ \\ School of Civil and Resources Engineering, University of Science and Technology Beijing, China \\ a1205768751@qq.com, bsuntc@ces.ustb.edu.cn, ‘625886833@qq.com, d56456367@qq.com
}

Keywords: nickel laterite ores; reduction; leaching; process

\begin{abstract}
Nickel laterite ores are important nickel resources, which are abundant and account for approximately $70 \%$ of the world nickel reserves. However, nickel in nickel laterite ores could not be extracted by conventional separation methods. Consequently, treating and utilizing nickel laterite ores efficiently is of vital importance. This article reviews hydrometallurgical processes, pyro metallurgical methods, and reduction roasting-magnetic separation technique with reference to current studies of treating processes for nickel laterite ores.
\end{abstract}

\section{Introduction}

Nickel is an essential nonferrous metal and widely used for stainless steel and alloy steel, electroplating, or catalysts in the process of hydrogenation of the petroleum chemical industry $[1,2]$.

Current nickel resources include nickel sulfide ores and nickel laterite ores in the land, which accounts for approximately $30 \%$ and $70 \%$ of the world nickel reserves, respectively. However, more than $60 \%$ of nickel production derives from nickel sulfide ores[3] because nickel in the sulfide ores can be easily enriched and recovered by conventional flotation as well as magnetic and gravity separation. As the high-grade nickel sulfide ores were exploited first and were progressively depleted, nickel laterite ores with low nickel-containing [4] have gradually become the main resources for nickel production [5-7].

Nickel from nickel laterite ores mostly occurs in nickel-enriched serpentines and olivines or iron oxide minerals as an isomorphism substitution in the lattice throughout the generation of nickel laterite ores from the weathering of ultrabasic rocks $[8,9]$, so it could not be extracted by conventional separation. In addition, nickel laterite ores are of low-grade, which are generally divided into three layers, namely limonitic, saprolitic, and garnieritic $[10,11]$. While, there are significant development advantages for nickel laterite ores. Firstly, they are abundant in reserves. Secondly, the deposits occur in the surface, which can be mined from the surface $[12,13]$. Therefore, profitable treating processes for efficient utilization of nickel laterite ores must be highly concerned and in-depth researched [1, 14].

An early review by Quast et al. [15] set the scene for the pre-concentration strategies of nickel laterite ores such as the removal of a coarse fraction from the feed, sink-float separation, gravity separation, magnetic separation, electrostatic separation, and flotation which are prior to subsequent hydrometallurgical or pyrometallurgical processing. While none of these techniques led to a potential upgrade of the laterite ore which will pay off the capital and operational cost of the full commercial plant. In order to meet the increasing demands for nickel and helping for exploiting nickel laterite ores more effectively, it is of vital importance about development of treating processes for nickel laterite ore. The aim of this paper is to review current studies about development of treating processes for nickel laterite ores in recent years.

\section{Overview of hydrometallurgical processes on treating nickel laterite ores}

The hydrometallurgical processes on treating nickel laterite ores included reduction roasting-ammonia leaching, pressure acid leaching, atmospheric acid leaching, and heap leaching.

The underlying principle of the roasting-ammonia leaching, pressure acid leaching, and atmospheric acid leaching is th at nickel and cobalt in the nickel laterite ores can transfer to the leaching 
solution, namely, ammonia or acid, because nickel and cobalt would form a complex with ammonia or dissolve in acid.

Reduction roasting-ammonia leaching is originally defined as the Caron process. The process is shown as follows (Fig. 1). Caron process is mostly suitable for limonite ores at a roasting temperature of $\sim 700-800{ }^{\circ} \mathrm{C}$ in the presence of a reductant where ammonia-ammonium carbonate leaching of the roasted product is reported to give $\sim 75-80 \%$ of $\mathrm{Ni}$ extraction and give $\sim 40-50 \%$ of Co extraction. Chen et al. [16] optimized extraction conditions of nickel and cobalt from low-grade laterite ores (Ni 1.17\%, Fe $45.56 \%$ ) using a: reduction roasting-ammonia leaching method. The optimum process conditions are as follows: in reduction roasting process, the mass fraction of reductant in the ore is $10 \%$, roasting time is $120 \mathrm{~min}$, roasting temperature is $750-800^{\circ} \mathrm{C}$; in ammonia leaching process, the liquid-to-solid ratio is $4: 1(\mathrm{~mL} / \mathrm{g})$, leaching temperature is $40{ }^{\circ} \mathrm{C}$, leaching time is $120 \mathrm{~min}$, and concentration ratio of $\mathrm{NH}_{3}$ to $\mathrm{CO}_{2}$ is $90 \mathrm{~g} / \mathrm{L}: 60 \mathrm{~g} / \mathrm{L}$. Under the optimum conditions, leaching efficiencies of nickel and cobalt were $86.25 \%$ and $60.84 \%$, respectively. Valix and Cheung [17] used elemental S in their study and reported that the presence of $\mathrm{S}$ can reduce the process temperature to $\sim 600{ }^{\circ} \mathrm{C}$ and also can give higher Ni recovery from both limonite and saprolite ores. The addition of $5 \% \mathrm{~S}$ in the reduction-roast process was reported to give $98 \% \mathrm{Ni}$ recovery from weathered saprolite ore and $80.6 \% \mathrm{Ni}$ recovery from limonite ore whereas without $\mathrm{S}$ addition $\mathrm{Ni}$ recoveries were $28 \%$ and $29 \%$ respectively from these ores at $600{ }^{\circ} \mathrm{C}$ roast temperature. On the basic of this process, Ma et al [18] optimized it by adding screening before reduction roasting. The ore sample used was an iron-rich laterite with a significant amount of iron (48.3\%) and a low amount of nickel (1.04\%). The purpose of screening was to remove some silicate minerals of a limonitic laterite ores from the Philippines. This move increased the extractions of nickel and cobalt from $84.0 \%$ and $35.5 \%$ to $87.9 \%$ and $47.4 \%$ respectively. Screening phase was also favorable to comprehensive recovery and utilization of iron, which increased the content of iron in leach residue to $60.7 \%$ without further processing.

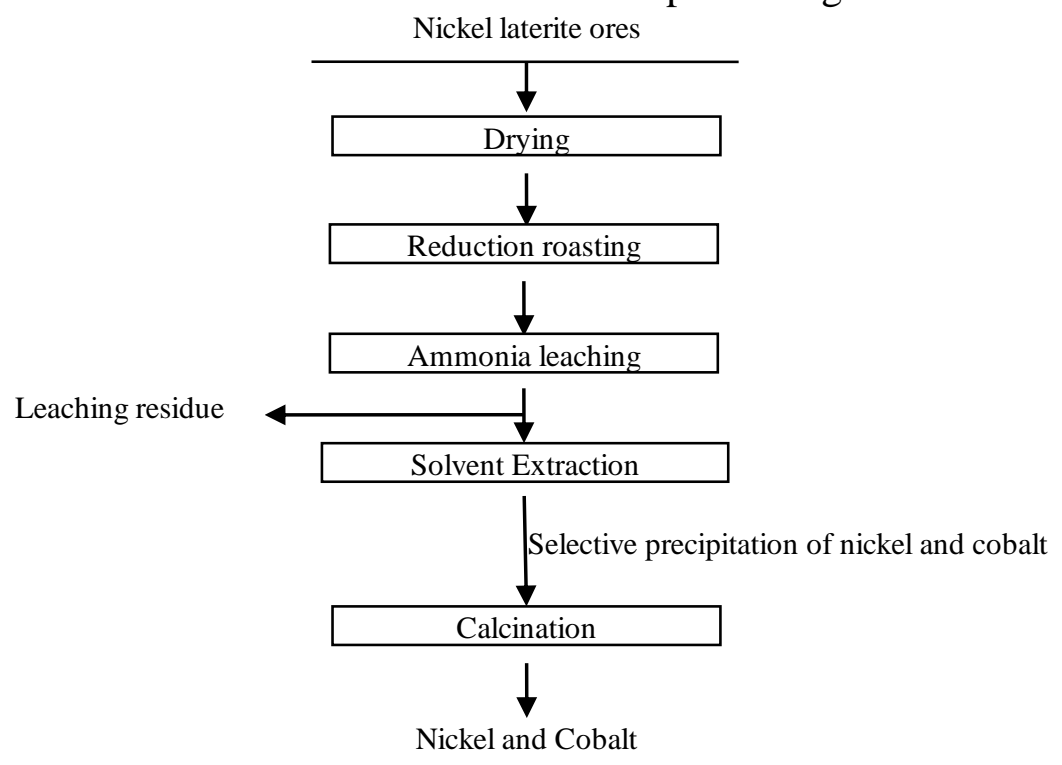

Figure 1. Flow chart of reduction roasting-ammonia leaching

In summary, nickel and cobalt could be extracted simultaneously by reduction roasting-ammonia leaching. However, the recovery rates of nickel and cobalt are low relatively, $\sim 75-80 \%$ of $\mathrm{Ni}$ extraction and $\sim 40-50 \%$ of Co extraction. In addition, reduction roasting-ammonia leaching process could not be used to treat laterite ores with high copper-containing, because copper could form a complex with ammonia like nickel and cobalt leading to separating with nickel and cobalt badly. Thirdly, it could not be used to treat high-silicon and high-magnesium nickel laterite ores. Compared to other hydrometallurgical processes for treating laterite ores, the drawback of reduction roasting-ammonia leaching is the requirement of high energy consumption due to the reduction roasting process. The disadvantages above-mentioned have always limited its wider practical production applications. In recent years, researchers have made a proper improvement to reduction 
roasting-ammonia leaching process, which improved $\mathrm{Ni}$ extraction to $>80 \%$. So the research about this technique returns to be a hotspot.

Pressure acid leaching mainly includes three steps, pulp preparation, leaching, and recovery of nickel and cobalt from leaching solution. It is generally at the high temperature of $250-270^{\circ} \mathrm{C}$ and at the high pressure of 4-5 MP, and it always makes a requirement for high equipment maintenance cost and also makes a demand on controlling process conditions. The entire process is depicted in the Fig. 2.The principle of pressure acid leaching process is that nickel and cobalt dissolve into acid under high pressure and high temperature. Generally, pressure acid leaching is carried out at high acid system where $25-100 \mathrm{~g} / \mathrm{L}$ free acid may remain in the final liquors so that nickel and cobalt extractions is greater than $90 \%$. Under the condition of high pressure and high temperature, extraction of nickel and cobalt is generally high. While It could not be used to deal with high-magnesium laterite ores, because magnesium would increase the acid consumption.

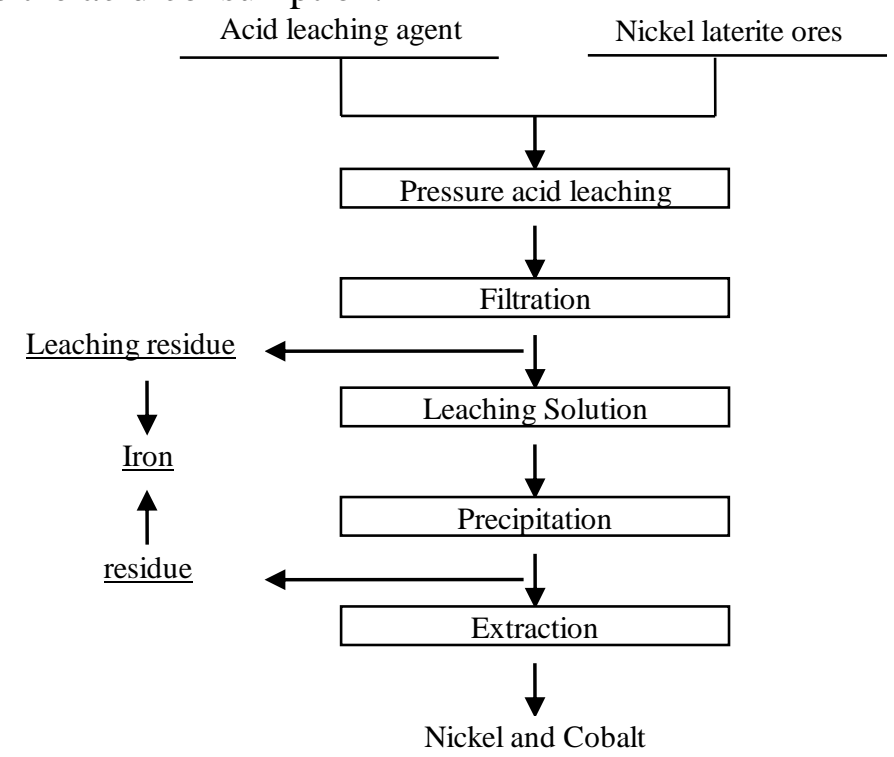

Figure 2. Flow chart of pressure acid leaching

The acid used most frequently is sulfuric acid [19-21]. The research of Johnson et al [20] showed that the extraction of nickel from nontronite-rich laterite ores was enhanced by either increasing the acid loading, or the addition of a small amount of sodium to the process water. In fresh process water, when acid loading was $380 \mathrm{~kg} / \mathrm{t}$ ore, nickel and cobalt extractions were $93.3 \%$ and $91.6 \%$, respectively. While in process water containing $5 \mathrm{~g} / \mathrm{L}$ sodium ion with acid loading of $320 \mathrm{~kg} / \mathrm{t}$ ore, nickel and cobalt extractions were $93.6 \%$ and $95.2 \%$, respectively. The results indicated that at least $15 \%$ less acid can be used to get the same extraction of nickel from a nontronite-rich laterite ore in process water containing $5 \mathrm{~g} / \mathrm{L}$ sodium ion, compared with the same ore in fresh process water. It also leads to less neutralisation cost because of the lower final free acidity of the autoclave discharge as well as less acid consumption. Kinetic study is a vital part for pressure sulfuric acid leaching. In one study [22], it was studied that the leaching kinetics of high pressure sulfuric acid leaching of laterite containing mainly maghemite and magnetite. It was found that the leaching kinetics followed the shrinking core model in the early and middle study, while it abided by acid diffusion control in the later stage. In short, these different kinetic models according to the differences of the main mineral laterite are good for exploiting and utilization of nickel laterite ores.

There have been practical applications by sulfuric acid pressure leaching treating laterite ores, such as Moa in Cuba and Ramu laterite ores in Papua New Guinea. Taking Ramu laterite ores as an example, the main components are $\mathrm{Ni}$ of $1.20 \%$, Co of $0.1 \%$, and $\mathrm{Fe}$ of $45 \%$. Under the conditions: pulp density of $>32 \%$, particle size of $200 \sim 4 \mu \mathrm{m}$, leaching temperature of $255^{\circ} \mathrm{C}$, pressure of $4.8 \mathrm{MPa}$ in autoclave, and leaching time of 50 60min, extractions of nickel and cobalt were as high as $\sim 96 \%$ and $\sim 94 \%$, respectively. There are some problems during production processes: ( $\mathrm{i}$ )The understanding on acid leaching was not enough so that part of impurity elements were out of 
specification, which would have an effect on the nickel and cobalt product as well as leading to increasing rejection ratio in the rubber-producing process. (ii) The nickel and cobalt product with high moisture-containing increased transportation costs by $\sim 20 \%$, affecting the economic benefits of the entire production process. The mechanism of high pressure acid leaching stage, neutralization and impurity removal, and selective precipitation should be researched in depth in order to select appropriate key parameters such as acid concentration, leaching temperature and time, selective precipitation et al. Meanwhile, it is important to find efficient way for dehydration of nickel and cobalt product to reduce transportation costs [23].

Besides, nitric acid and hydrochloric acid are also used as leaching agents during pressure acid leaching in recent studies.

Nitric acid pressure leaching (NAPL) was patented in 2008. In 2008, Wang et al. [24] announced their invention. They pointed out that nitric acid could be used as leaching agent of pressure leaching to treat high magnesium-containing nickel laterite ores. The process is as follow in detail. Firstly, high-magnesium nickel laterite ores are crushed and grounded to particle size of $75 \mu \mathrm{m}(\geq 80 \%)$. Secondly, the mixture of nitric acid and the nickel laterite ore with a certain ratio of acid/solid are poured to an autoclave for pressure leaching under the process conditions (nitric acid concentration of $500 \sim 1500 \mathrm{~kg} / \mathrm{t}$ ore, liquid/solid ratio of $3 \sim 10: 1$, leaching temperature of $120 \sim 200^{\circ} \mathrm{C}$, leaching time of 30 120min ,shaker speed of 300 500 rpm). . Thirdly, purify and iron removal by precipitation through adding $\mathrm{MgCl}_{2}$ as neutralizing agent and controlling $\mathrm{pH}$ of 2.5 3.5, resulting in iron concentration of lower $0.07 \mathrm{~g} / \mathrm{L}$ in leaching solutions. Fourthly, selective hydroxide precipitates of nickel and cobalt were through adding $\mathrm{MgCl}_{2}$ as neutralizing agent and controlling $\mathrm{pH}$ of 6.5 8.0, which were dissolved and extracted to obtain nickel and cobalt product. Extraction of nickel and cobalt all reached $95 \%$, and extraction of magnesium reached $98 \%$. Nitric acid could be recovered and reused. In addition, autoclave would not be scabby, so this process is suitable for large-scale production and use.

Ma et al. [25] used nitric acid pressure leaching as well as using sulfuric acid leaching to extract nickel and cobalt from an Indonesian limonitic laterite whose major minerals were goethite and magnetite. The optimal conditions were as follows: acid/ore ratio of $380 \mathrm{~kg} / \mathrm{t}$ ore, leaching temperature of $190^{\circ} \mathrm{C}$, leaching time of $60 \mathrm{~min}$, pulp density of $32.5 \%$, and particle size of $150 \mu \mathrm{m}(100 \%)$. Using the typical HPAL process, the nickel and cobalt extractions were only $74.5 \%$ and $72.2 \%$, respectively. And the iron concentration in the leach liquor was as high as $12.5 \mathrm{~g} / \mathrm{L}$. However, the selective leaching of the ore was achieved, with more than $85 \%$ of extracted nickel and cobalt and only $1.80 \mathrm{~g} / \mathrm{L}$ of extracted iron. By contrast, there are some significant advantages of NAPL compared with HPAL. The extraction of nickel and cobalt were obviously improved, and the extraction of iron remarkably dropped. Moreover, residual acid using NAPL was lower than that using HPAL. Nitric acid acted as an oxidant to besides acting as a lixiviant, which is helpful for the formation of hematite and resulting in a low iron concentration in the leach liquor. And the leaching process of NAPL may occur Reactions (1-4). The leaching residues had high iron content with no sulfur, which is suitable as raw materials for iron-making.

$$
\begin{aligned}
& \mathrm{FeOOH}_{(\mathrm{S})}+3 \mathrm{H}^{+}{ }_{(\mathrm{aq})} \rightarrow \mathrm{Fe}^{3+}{ }_{(\mathrm{aq})}+2 \mathrm{H}_{2} \mathrm{O}_{(\mathrm{l})} \\
& \mathrm{Fe}_{3} \mathrm{O}_{4}(\mathrm{~S})+8 \mathrm{H}^{+}{ }_{(\mathrm{aq})} \rightarrow 2 \mathrm{Fe}^{3+}{ }_{(\mathrm{aq})}+\mathrm{Fe}^{2+}{ }_{(\mathrm{aq})}+4 \mathrm{H}_{2} \mathrm{O}_{(\mathrm{l})} \\
& 3 \mathrm{Fe}^{2+}{ }_{(\mathrm{aq})}+\mathrm{NO}_{3}^{-{ }_{(\mathrm{aq})}}+4 \mathrm{H}^{+}{ }_{(\mathrm{aq})} \rightarrow 3 \mathrm{Fe}^{3+}{ }_{(\mathrm{aq})}+\mathrm{NO}_{(\mathrm{g})}+2 \mathrm{H}_{2} \mathrm{O}_{(\mathrm{l})} \\
& 2 \mathrm{Fe}^{3+}{ }_{(\mathrm{aq})}+3 \mathrm{H}_{2} \mathrm{O}_{(\mathrm{l})} \rightarrow \mathrm{Fe}_{2} \mathrm{O}_{3(\mathrm{~S})}+6 \mathrm{H}^{3+}{ }_{(\mathrm{aq})}
\end{aligned}
$$

Ma et al. [26] made a series of pilot-scale tests about nitric acid pressure leaching for five limonitic laterite ores. Under the optimal leaching conditions (nitric acid/ore of $380 \mathrm{~kg} / \mathrm{t}$, particle size of 
$150 \mu \mathrm{m}(100 \%)$, pulp density of $32.5 \%$, and leaching at $190^{\circ} \mathrm{C}$ for $\left.60 \mathrm{~min}\right)$, average extractions of nickel and cobalt were $84.52 \%$ and $83.85 \%$, respectively. They also made pilot-scale tests about nitric acid pressure leaching for three high magnesium-bearing ore. Under the optimal leaching conditions (nitric acid/ore of $800 \mathrm{~kg} / \mathrm{t}$, particle size of $150 \mu \mathrm{m}(100 \%)$, pulp density of $28.5 \%$, and leaching at $150^{\circ} \mathrm{C}$ for 60min, average extractions of nickel and cobalt were $98.22 \%$ and $99.01 \%$, respectively.

Zhang et al. [27] used pressure hydrochloric-acid selective leaching to extract nickel and cobalt from saprolitic laterite ore containing $1.37 \% \mathrm{Ni}$ and $18.8 \% \mathrm{Fe}$. The results showed that pressure hydrochloric-acid selective leaching is a viable method for efficiently leaching nickel from laterite ores. The optimal leaching conditions were as follow: $\mathrm{HCl}$ concentration of $350 \mathrm{~g} / \mathrm{L}, 1 / \mathrm{s}$ ratio of 1.0, leaching temperature of $150{ }^{\circ} \mathrm{C}$, and leaching time of $90 \mathrm{~min}$. Under optimal conditions, the extraction of nickel and cobalt were $89.4 \%$ and $97.3 \%$, respectively. For early stage of leaching, some of iron would dissolve in the leaching solution via Reaction (5), which was followed by goethite precipitation via Reaction (6). Subsequently, the dehydration of goethite occurs through Reaction (7). However, $\mathrm{NiCl}_{2}$ did not precipitate as an oxide, because the precipitation of $\mathrm{FeCl}_{4}^{-}$in the form of $\mathrm{Fe}_{2} \mathrm{O}_{3}$ is more thermodynamically favorable than the precipitation of $\mathrm{Ni}^{2+}$ as $\mathrm{NiO}$. So the pressure hydrochloric-acid leaching had also realized selective pressure leaching.

$$
\begin{gathered}
\mathrm{FeOOH}_{(\mathrm{S})}+4 \mathrm{HCl} \rightarrow \mathrm{FeCl}_{4}^{-}+2 \mathrm{H}_{2} \mathrm{O}+\mathrm{H}^{+} \\
\mathrm{FeCl}_{4}^{-}+2 \mathrm{H}_{2} \mathrm{O} \rightarrow \mathrm{FeOOH}+3 \mathrm{H}^{+}+4 \mathrm{Cl}^{-} \\
2 \mathrm{FeOOH} \rightarrow \mathrm{Fe}_{2} \mathrm{O}_{3}+\mathrm{H}_{2} \mathrm{O}
\end{gathered}
$$

As same as pressure leaching processes, the most frequently used acid during atmospheric acid leaching is sulfuric acid [28]. And there are lots of researches about using hydrochloric acid, nitric acid, and organic acid as leaching agent to extract nickel from nickel laterite ores [29-31].

Chen et al. [32] used atmospheric sulfuric acid leaching treating laterite ore with the nickel content of $1.27 \%$ and the iron content of $39.93 \%$. Results showed that the ultrasonic field has a significant effect on the extractions of nickel and iron. Optimal leaching conditions were found as follows: particle size of $74 \mu \mathrm{m}(95 \%)$, leaching temperature of $80^{\circ} \mathrm{C}$, sulfuric acid concentration of $190 \mathrm{~g} / \mathrm{L}$, solid/liquid ratio of $20 \%$, leaching time $2 \mathrm{~h}$, stirring speed of $400 \mathrm{rpm}$. Under the same conditions, extractions of nickel and iron reached $98.35 \%$ and $91.28 \%$ with the ultrasonic field exertion working $4 \mathrm{~min}$ every $5 \mathrm{~min}$. In contrast, extractions of nickel and iron were only $78.84 \%$ and $80.26 \%$ without the ultrasonic field. A iron product with iron content of $63.56 \%$ were obtained by precipitation and roasting. The final recovery rates of nickel and iron were $95.62 \%$ and $86.50 \%$, respectively. Kursunoglu and Kaya [33] extracted nickel, cobalt and iron from Caldag laterite ores using atmospheric sulfuric acid leaching. extractions of nickel, cobalt and iron were $91.9 \%, 93.5 \%$ and $80.5 \%$ were achieved under the following leaching conditions: ore particle size of $212 \mu \mathrm{m}$, sulfuric acid concentration of $2 \mathrm{~mol} / \mathrm{L}$, leaching time of $6 \mathrm{~h}$, pulp density of $10 \% \mathrm{w} / \mathrm{v}$, leaching temperature of $90^{\circ} \mathrm{C}$ and shaker speed of $500 \mathrm{rpm}$. Some studies of atmospheric sulfuric acid leaching have focused on the leaching kinetics of nickel and cobalt. MacCarthy et al. [28] studied the effect of temperature (70 vs. $90{ }^{\circ} \mathrm{C}$ ) and solid loading (30 vs. $45 \%$ ) on leaching kinetics of value $\mathrm{Ni} / \mathrm{Co}$ and gangue $\mathrm{Fe} / \mathrm{Mg}$ metal extraction from low grade $\mathrm{Ni}$ laterite ore $(\sim 1.1 \% \mathrm{Ni})$ at $\mathrm{pH} 1$ for $4 \mathrm{~h}$ and stirring speed of $600 \mathrm{rpm}$. At $70^{\circ} \mathrm{C}$, solid loading had negligible impact on leach kinetics and only $\sim 14-18 \% \mathrm{Ni}, \mathrm{Co}, \mathrm{Mg}$ extraction and $\sim 5 \% \mathrm{Fe}$ extraction was achieved. While at $90{ }^{\circ} \mathrm{C}$, extractions of $\mathrm{Ni}$ and Co were dramatically increased to $56 \%$ and $50 \%$ for $45 \%$ solid loading, and $67 \%$ and $56 \%$ for $30 \%$ solid loading, respectively. It indicated that the effect of temperature was greater than solid loading. MacCarthy et al. [34] also studied the effect of stirring speed in the range of 600-1000rpm on the leaching behavior. Results showed stirring speed had no noticeable effect. Slurry viscosity and shear 
yield stress dramatically increased with time. However, the increasing of rheology had not a noticeable influence on the kinetics.

Some scholars $[2,29,31]$ have completed studies on different laterite ores in the atmosphere hydrochloric acid leaching conditions. Li et al. [2] studied the effect of physicochemical factors on laterite ore leaching in hydrochloric acid. The nickel content of raw ore was $0.87 \%$, and the cobalt content was $0.061 \%$. nickel and cobalt could be extracted effectively at the leaching conditions as follows: acid concentration of $8 \mathrm{~mol} / \mathrm{L}$, the particle size of $-150 \mu \mathrm{m}(100 \%)$, stirring speed of $300 \mathrm{rpm}$, leaching temperature of $80^{\circ} \mathrm{C}$, solid/liquid ratio of $25 \%$ and leaching time of $2 \mathrm{~h}$. Extractions of $\mathrm{Ni}, \mathrm{Co}$, $\mathrm{Mg}$, and Fe under these conditions were $92.3 \% 61.5 \%, 93.5 \%$, and 95.5\%, respectively. Wang et al. [31] studied the characterization and atmosphere hydrochloric acid leaching of a typical low-grade limonitic laterite (Ni 0.82\%, Fe 49.92\%, Co 0.078\%). The optimum leaching conditions were as follow: an a/o of 1.25, an 1/s of 4, a leaching temperature of $80{ }^{\circ} \mathrm{C}$, and a leaching time of $2 \mathrm{~h}$. Extractions of $\mathrm{Ni}, \mathrm{Co}$, and $\mathrm{Fe}$ under these conditions were $95.1 \% 99.0 \%$, and $94.6 \%$, respectively. The dissolution behavior of minerals showed that simplified leachability sequence was as follows: siderite $>$ chrysotile $>$ magnetite $>$ maghemite $>$ goethite $>$ hematite $>$ chromite $\approx$ ringwoodite. Meng et al. [35] used alkaline oxidation for comprehensive recovery of $\mathrm{Mn}$ and $\mathrm{Mg}$ as well as $\mathrm{Ni}$ and Co based on atmospheric hydrochloric acid leaching. The optimal conditions for the acid leaching process included a $\mathrm{HCl}$ concentration of $10 \mathrm{wt} . \%$, leaching time of $1.0 \mathrm{~h}$, leaching $\mathrm{pH}$ of 1.0 , and leaching temperature of $30{ }^{\circ} \mathrm{C}$. Under these conditions, the recovery values of $\mathrm{Ni}, \mathrm{Co}, \mathrm{Mn}$, and $\mathrm{Mg}$ were found to be approximately $100 \%, 93.07 \%, 93.76 \%$, and $99.07 \%$, respectively. Under optimal conditions for alkaline oxidation including a $\mathrm{NaOH}$ concentration of 5 wt. $\%, \mathrm{H}_{2} \mathrm{O}_{2}$ concentration of $10 \mathrm{wt} . \%, \mathrm{HCl}$ concentration of $10 \mathrm{wt} . \%$, and oxidation $\mathrm{pH}$ of 9.0 , the recoveries of $\mathrm{Ni}, \mathrm{Co}, \mathrm{Mn}$, and $\mathrm{Mg}$ are nearly $100 \%, 95.46 \%, 92.90 \%$, and $98.88 \%$, respectively. Under alkaline conditions, the oxidizability of $\mathrm{Mn}^{2+}$ is weakened, whereas its reducibility is enhanced. $\mathrm{H}_{2} \mathrm{O}_{2}$ can oxidize $\mathrm{Mn}$ from the +2 oxidation state to the +4 oxidation state. $\mathrm{Ni}^{2+}, \mathrm{Co}^{2+}$, and $\mathrm{Mn}^{2+}$ precipitated in the form of $\mathrm{Ni}(\mathrm{OH})_{2}, \mathrm{Co}(\mathrm{OH})_{2}$, and $\mathrm{MnO}_{2}$ through added $\mathrm{NaOH}$ used to controlling the $\mathrm{pH}$, leaving $\mathrm{Mg}^{2+}$ in the liquor. Then $\mathrm{Ni}$ and $\mathrm{Co}$ were leached in the acid, and the separation of manganese was realized since $\mathrm{MnO}_{2}$ does not dissolve in dilute acidic liquors.

Agacayak et al. [10] used nitric acid as solution for leaching of nickel from a typical limonitic ore with the nickel content $1.84 \%$ and the iron content $23.14 \%$. Experiments were carried out by agitation leaching using $1 / 50 \mathrm{~g} / \mathrm{ml}$ (solid-liquid ratio) in a covered $1 \mathrm{~L}$ pyrex beaker in a temperature-controlled water bath. When the conditions were determined: stirring speed of $200 \mathrm{r} / \mathrm{min}$, acid concentration of 2 $\mathrm{mol} / \mathrm{L} \mathrm{HNO}_{3}$, temperature of $80{ }^{\circ} \mathrm{C}$ and particle size of $<38 \mu \mathrm{m}, 98 \%$ of nickel extraction was obtained for 240 min leaching period. In this research, shrinking core model was applied to the experiment results about the effects of leaching temperature in the range of 40-90 ${ }^{\circ} \mathrm{C}$ and nitric acid concentration in range of 0.1-2 mol/L on nickel dissolution rate. McCarthy and Brock [36] introduced the direct nickel process namely nitric acid leaching under atmospheric pressure, which were designed to treat all types of nickel laterite ores. The ore was mined and then fed to a comminution plant for crushing to $<2 \mathrm{~mm}$. It was then mixed with the nitric acid to a solids loading of $\sim 20-30 \%$ and fed to the leaching tanks heated to $110^{\circ} \mathrm{C}$. The leaching time was $2-6 \mathrm{~h}$ with $4 \mathrm{~h}$ being typical. This process proved to be simple and safe to operate on a continuous basis. The simplified schematic of the direct nickel process is shown in Fig.3. 


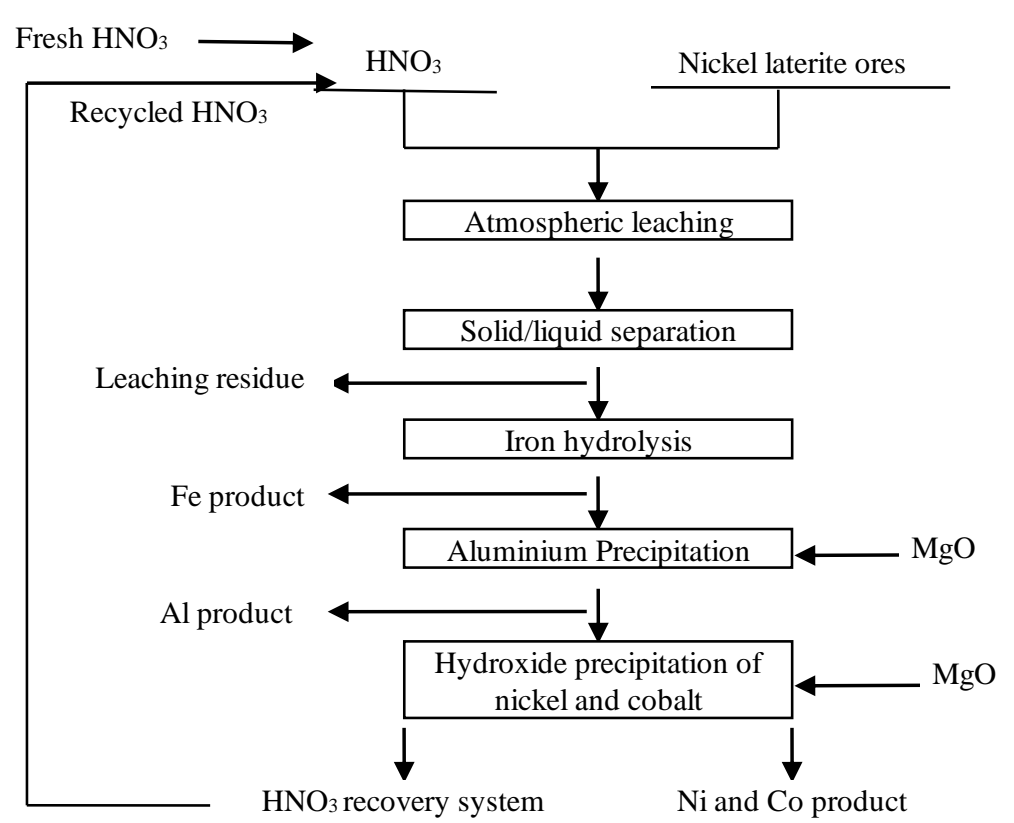

Figure 3. Simplified schematic of the direct nickel process

Organic acids are less stable and more environment friendly than inorganic acids. Several investigations about leaching kinetics of different laterite ores under atmospheric leaching conditions using critic acid have been performed [30, 37]. Astuti et al. [30] used citric acid as the leaching agent under atmosphere pressure for nickel extraction of an Indonesian saprolitic ore with the nickel content $1.76 \%$. The highest Ni recovery $(95.6 \%)$ was achieved under the leaching conditions of ore particle size of 212-355 $\mu \mathrm{m}$, critic acid concentration of $1 \mathrm{~mol} / \mathrm{L}$, leaching time of 15 days, pulp density of $20 \% \mathrm{w} / \mathrm{v}$, leaching temperature of $40^{\circ} \mathrm{C}$ and shaker speed of $200 \mathrm{rpm}$. It was reported in this research that the shrinking core model was appropriate for describing the leaching kinetics of this ore in critic acid solutions at atmospheric leaching. In addition, Astuti et al. [37] have made an comparison of atmosphere citric leaching kinetics of nickel from different saprolitic ores with the nickel contents $1.76 \%$ (SS ore) and $1.28 \%$ (SH ore), respectively. The maximum leaching efficiency of nickel was achieved from SS ore and SH ore were $96 \%$ and $73 \%$, respectively. The experiment results showed that the nickel leaching rates from SS ore was always higher than SH ore under the same leaching conditions. Meanwhile, it was found that serpentine is more easily leached than goethite and talc by using XRD and FTIR spectroscopy. Kursunoglu and Kaya [38] investigated the dissolution behavior of Caldag lateritic nickel ore subjected to a sequential organic acid leaching method. After two leaching step, namely, $8 \mathrm{~h}(4 \mathrm{~h}+4 \mathrm{~h})$ of leaching with organic acids $(0.5 \mathrm{~mol} / \mathrm{L}$ citric $+0.5 \mathrm{~mol} / \mathrm{L}$ oxatic ) in sequence at $90^{\circ} \mathrm{C}, 89.63 \% \mathrm{Ni}, 82.89 \% \mathrm{Co}$, and $69.63 \% \mathrm{Fe}$ were leached from the lateritic nickel ore (Ni 1.0813\%, Fe 21.916\%, Co 0.0493\%).

In conclusion, pressure acid leaching offers several advantages, such as high extraction rates of nickel/cobalt and high efficiency. But there are also several disadvantages. Because of pressure condition, acid environment during leaching step, and complex neutralization-impurity removal, pressure acid leaching requires complex infrastructure facilities. Also, excess free acid is required for leaching of nickel and cobalt as far as possible. In addition, pressure sulfuric acid leaching process is only suitable for treating low-aluminum and low-magnesium limonitic laterite. Thirdly, pressure nitric acid leaching process and pressure selective hydrochloric acid leaching are still not mature and needing further optimization. When it is compared with pressure acid leaching, atmospheric acid leaching has relatively less demands for the leaching equipment due to atmospheric pressure conditions, and the extraction rates of nickel is relatively low. . In addition, it can be used to leach relatively low grade nickel laterite ores [33]. Nitric acid leaching is widely applicable for treating nickel laterite ores. The developments of nitric acid leaching processes are favorable for production application of hydrometallurgical processes. Organic acids leaching is more environment friendly than inorganic 
acids leaching, but the leaching time for organic acids leaching is long. Complicated and long processes are disadvantages for both of pressure acid leaching and atmospheric acid leaching.

Heap leaching is also always used for Ni recovery from lower grade laterites in various parts of the world. There are a series of advantages about heap leaching process, such as low infrastructure investment, short construction period, simple flow process, increasing resource utilization, low production cost and so on due to its process conditions. These advantages are helpful to its potential to be widely used. Liu et al. [39] made a pilot experiment on processing of laterite ore with a combined process consisting of heap leaching and atmosphere tank leaching. Ore with size of $+0.25 \mathrm{~mm}$ after scrubbing and screening was feed to heap leaching. It was found that the accumulated extraction rate of Ni was about $80 \%$ after column leaching with heap height of $4 \mathrm{~m}$, acid consumption at $700 \mathrm{~kg} / \mathrm{t}$ and leaching time of $142 \mathrm{~d}$. Results showed that heap leaching is not high-efficient. Of course, no process is perfect. People should pay attention to the applicability of every process.

The developments of acid leaching processes are favorable for production application of hydrometallurgical processes. It really matters to improving and optimizing the hydrometallurgical processes on treating nickel laterite ores, along with more and more important development and utilization of laterite.

\section{Overview of pyrometallurgical methods on treating nickel laterite ores}

The pyrometallurgical methods on treating nickel laterite ores consisted of producing ferronickel throughout rotary kiln reduction-electric furnace smelting and producing nickel-sulphide matte in reduction-smelting [40]. Pyrometallurgical methods are mostly suitable for saprolitic laterites and garnieritic laterites with high nickel-containing [11, 32, 41]. Nickel and iron of the ores are reduced into metallic states during the reduction process and then the ferronickel product is separated from slag through smelting. Producing nickel-sulphide matte in reduction-smelting is a variation of extracting ferronickel throughout reduction and smelting by adding sulfur to the feed calcine in the smelting stage.

Rotary kiln reduction-electric furnace smelting is namely as RKEF, whose main steps are drying, calcination, prereduction and smelting. The flow chart of RKEF process is depicted in the Fig. 4. Due to the metallogenic mechanism of laterite ore, laterite ores generally contain high free water, which is the necessary reason for the drying phase in RKEF process. Calcination phase is used to removal of bond water. Keskinkilic et al. [42] investigated calcination characteristics of laterite ores (Ni 1.26\%, $\mathrm{Fe} 32.6 \%$ ). The complete calcination process contained two aspects, the removal of chemically bound water during the goethite-haematite transformation and the elimination of volatiles in the $350-700^{\circ} \mathrm{C}$ interval. As a result, $700^{\circ} \mathrm{C}$ should be selected as the calcination temperature for effective elimination of chemically bound water and all volatiles. Zevgolis et al.[11] studied phase transformation of laterite ores during preheating and reduction with carbon monoxide in order to understand better the extent of their effect on the final reduction obtained. Transformation of goethite to hematite and decomposition of chlorite and serpentine, were identified during preheating. Higher iron metallization was achieved for the ore in which goethite is the main iron mineral and reduction goes up to 95\%, whereas it goes up to $50 \%$ for the ore in which hematite is the main iron mineral. The higher reducibility seems to be due to the higher specific surface area of the goethitic type of ore. 


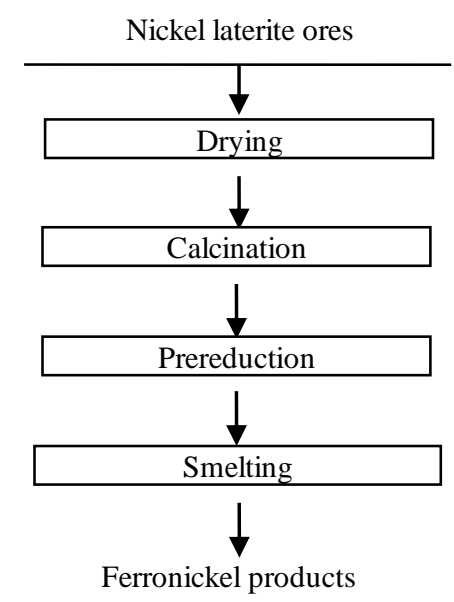

Figure 4. Flow chart of rotary kiln reduction-electric furnace smelting

It is critical of controlling the prereduction in the rotary kiln reduction, since it strongly influences the recovery of nickel and the grade of ferronickel. Bunjaku et al. [12] studied the prereduction of three different saprolitic laterites by various reducing gases and explored the relationship between the reducibility, ore mineralogy and reducing gas. The nickel contents of Colombia-1, Colombia-2, and Mirabela ores used were $0.76 \%, 2.3 \%$, and $2.6 \%$, respectively. The ores had high magnesium (14.7\%-26.6\%) and silica contents (44.9\%-49.6\%). It was found that the reduction rate and degree of removable oxygen at $750^{\circ} \mathrm{C}$ and $900{ }^{\circ} \mathrm{C}$ in $\mathrm{CO} / \mathrm{CO}_{2}(72 \%: 28 \%)$ was lower compared to reduction experiments in $\mathrm{H}_{2} / \mathrm{N}_{2}(72 \%: 28 \%)$. And the reducibility of the samples seemed to depend on mineralogy and their modes of decomposition and recrystallization. Taking for granted the stepwise gaseous reduction of haematite to metallic iron, as well as the reduction of nickel silicates into metallic nickel, it was recommended to use $\mathrm{CO}$ reducing gas to achieve the highest metallisation for nickel. Pournaderi et al. [4] studied effects of temperature, coal amount, and reduction time on prereduction of a laterite ore ( $\mathrm{Ni} 1.26 \%, \mathrm{Fe} 32.6 \%$ ). It was reported that the metallization of $\mathrm{Fe}$ was limited up to $900^{\circ} \mathrm{C}$ and increased rapidly at higher temperature. And the metallization of $\mathrm{Ni}$ and $\mathrm{Co}$ increased when the temperature was increased from 700 to $800^{\circ} \mathrm{C}$, almost leveled off up to $900^{\circ} \mathrm{C}$ and then increased up to $1100^{\circ} \mathrm{C}$. Iron had a dual role at higher temperature. It accelerated the Boudouard reaction and at the same time, possibly reacted with $\mathrm{Ni}$ and $\mathrm{Co}$ oxides through the Reaction (8-9) given below to produce metallic elements. The increase in coal amount did not affect Fe metallization up to $900^{\circ} \mathrm{C}$. It affected the nickel reduction equally at all temperatures, while it had no effect on the metallization of Co. At $1100{ }^{\circ} \mathrm{C}$, reduction reactions were fast and almost ceased within 2400s. But the reaction required longer durations for completion at $1000^{\circ} \mathrm{C}$.

$$
\begin{array}{r}
\mathrm{NiO}+\mathrm{Fe}=\mathrm{Ni}+\mathrm{FeO} \\
\mathrm{CoO}+\mathrm{Fe}=\mathrm{Co}+\mathrm{FeO}
\end{array}
$$

Based on the process of coal-based self-reduction and melting separation at high temperature, Cao et al. [43] investigated the effect of process factors on the reduction of the laterite ore with the low nickel content $0.78 \%$ and the high iron content $46.54 \%$. The results showed that when $\mathrm{CaF}_{2}$ and saked lime were added simultaneously, the metal could well separate from slag. And with the C/O mole ratio improving from 1.0 to 1.2 , the content of $\mathrm{Ni}$ in metallic particles increases from $1.37 \%$ to $1.42 \%$ and the yield of $\mathrm{Ni}$ enhances from $88.74 \%$ to $92.12 \%$. But the yield of Fe has little changed. Also reported that low $\mathrm{C} / \mathrm{O}$ mole ratio restrains the reduction of ferric oxide and increase the content of $\mathrm{Ni}$ in metal, while the recovery rate of $\mathrm{Ni}$ decreases. Consequently, selection of additive species and $\mathrm{C} / \mathrm{O}$ mole ratio should be optimized.

$\mathrm{Li}$ et al. [41] studied the reduction of nickel from low-grade nickel laterite ore (Ni 1.09\%, Fe 9.12\%) using a solid-state deoxidization method. The conversion percentage of the total nickel to metallic 
nickel increased rapidly with increasing CO content, with a maximal $\alpha_{\mathrm{Ni}}$ of $96 \%$. And $\alpha_{\mathrm{Ni}}$ of up to $80 \%$ could be obtained when using anthracite as a solid reductant. Using $\mathrm{CO}$ as reductant, the conversion percentage of the total nickel to metallic nickel increased with increasing reaction temperature and time initially, and then remained steady with further increases, but decreased abruptly at a temperature of $850^{\circ} \mathrm{C}$ because of phase transformation. While using anthracite as reductant, the $\alpha_{\mathrm{Ni}}$ generally increased with increasing reduction temperature, and the $\alpha_{\mathrm{Ni}}$ increased with an increase in the reduction time but decreased slowly as the time increased above $80 \mathrm{~min}$. Researches on reduction characteristics of nickel from nickel laterite ore using different reductants reflect the importance about cooperative effects of reductant types/dosage, reduction temperature and time, and have some theoretical significance and practical values for the development of the pyrometallurgical methods.

During the rotary kiln reduction-electric furnace smelting process, it is needed to carry out smelting at $\sim 1500-1600{ }^{\circ} \mathrm{C}$, which leads to the high energy consumption of the process. The noteworthy disadvantage of high energy intensity limits its commercial applications for treating low nickel-containing laterite ore in order to ensure the economic benefits. To address the problem, Ma et al. [1] have studied smelting of nickel laterite ore with the content $\mathrm{NiO} 2.2 \%$ and the $\mathrm{Fe}_{2} \mathrm{O}_{3} 20.0 \%$ at a lower temperature. Slag properties can influence metal/slag separation and operating temperature [44]. Therefore, Ma et al. [1] investigated the optimization of salg and alloy systems to lower the smelting temperature. They lower the smelting temperature to $1450^{\circ} \mathrm{C}$, based on the high melting points of ferronickel alloys - over $1450^{\circ} \mathrm{C}$. Ten grams of laterite ore were well mixed with flux and graphite powder in a mortar and then pressed into pellets. In some experiments, the Mo metal pieces or $\mathrm{MoO}_{3}$ powders were blended. The pelletized samples was then placed into an aluminum crucible. The sample was heated and prereduced in the hot zone of the furnace under an $\mathrm{Ar}$ atmosphere at $1100^{\circ} \mathrm{C}$ for $60 \mathrm{~min}$. Then, each prereduced sample was subjected to one of two heating temperature profiles: (I) heating from $1100^{\circ} \mathrm{C}$ up to the smelting temperature of $1450^{\circ} \mathrm{C}$ at a rate of $7{ }^{\circ} \mathrm{C} / \mathrm{min}$ and then maintained at $1450^{\circ} \mathrm{C}$ for $10 \mathrm{~min}$; and (II) placed immediately at the smelting temperature of $1450^{\circ} \mathrm{C}$ and held there for $60 \mathrm{~min}$. One possible way to lower the melting point of ferronickel alloys is to add another metal to form a Fe-Ni-M ternary alloy. The curve in an Ellingham diagram of Mo which is also common raw material for steels lies between the curves for $\mathrm{Fe}$ and $\mathrm{Ni}$, so it is selected to be added to the smelter to form a Fe-Ni-Mo alloy for lowering the smelting temperature. When $\mathrm{Mo} / \mathrm{MoO}_{3}$ was added $1 \%$, it can be seen that Mo additions were melted to form a Fe-Ni-Mo alloy, which effectively separates with the slag. In addition to decreasing the melting point of ferronickel alloys, the function of Mo addition can also be described as a "collector" of ferronickel sponges. Liu et al. [45] have proposed an energy strategy with two energy saving measures for reduction energy loss in the rotary kiln-electric furnace. The first one is to recover the waste heat of exhaust gas from the rotary kiln for drying the wet laterite ores. The second one is to recycle the furnace gas from the electric furnace into the rotary kiln as fuel. These above-mentioned researches of this technology are beneficial for commercial application of pyrometallurgical processes.

In conclusion, the pyrometallurgical processes are of mature technology and simple flow. However, comprehensive recovery of cobalt could not be achieved. Besides, the disadvantages of pyrometallurgical processes also include the requirement of high grade ores for the raw ores and substantial energy input. So in order to decrease energy consumption of pyrometallurgical processes, it requires more involvements of mineral processing engineers.

\section{Overview of reduction roasting-magnetic separation technique on treating nickel laterite ores}

Hydrometallurgical processes are complex and long [46], but low energy. By contrast, pyrometallurgical processes are simple but energy intensive, and it has requirement on the raw nickel laterite ore of high nickel containing [1]. To overcome the limitation of pyrometallurgical processes, scholars have proposed replacing the smelting stage with magnetic separation to recover ferronickel particles generated during the roasting reduction stage in recent years. Reduction roasting-magnetic 
separation is a novel and promising nickel extraction process that exhibits potential for popularization and applications, because it offers advantages such as simplicity and low energy consumption simultaneously $[47,48]$. It can be used to handle various types of laterite ores. In the reduction roasting stage, nickel and iron are reduced to the metallic states in the temperature of $1000 \sim 1200^{\circ} \mathrm{C}$. The ferronickel particles are separated from impurities in the magnetic separation stage after the roasted ores are crushed and ground. The recovery rate of nickel is generally higher than $90 \%$.

Selective reduction-magnetic separation process is mainly put forward in order to improve the nickel grade of ferronickel products. Nickel should be reduced as much as possible and the metallization of iron should be restrained to achieve selective reduction of nickel and obtain the ferronickel product with high nickel grade. With regard to the selectivity of reduction, it is not possible and inappropriate for complete selectivity, because iron should be metallized to some extent and act as a carrier [13]. In addition, it is vital to maximizing the ferronickel particle size so that the ferronickel alloy could be recovered by subsequent grinding and magnetic separation. Zhu [49] studied the reduction of a limontic laterite ore and a saprolitic laterite ore. The resulted showed that an appropriate increase of silicate minerals was beneficial to nickel concentration by suppressing iron oxide reduction. The resulted also showed that the addition of calcium sulfate remarkably promoted the ferronickel particle growth. In addition, the grade and recovery rate of nickel were sensitive to the reductant dosage. Jiang et al. [47] used selective reduction-magnetic separation process for treating a high iron-containing laterite ore ( $\mathrm{Ni} 1.49 \%$, Fe 34.69\%), with the addition of sodium sulfate. The ferronickel products with a nickel grade of $9.87 \%$ and a nickel recovery rate of $90.90 \%$ was obtained, when laterite ores was reduced at $1200^{\circ} \mathrm{C}$ for $50 \mathrm{~min}$ with the addition of $10 \mathrm{wt} . \% \mathrm{Na}_{2} \mathrm{SO}_{4}$ and 2 wt. $\%$ coal. Elliott et al. [14] studied selective reduction of a limonitic ore with the nickel content of $1.38 \%$ and the iron content of $45.70 \%$. They used a two-stage reduction and thermal growth process to produce a ferronickel product, an initial reduction roast of the ore with $6 \%$ coal and $4 \%$ sulphur additions at $600^{\circ} \mathrm{C}$ for $1 \mathrm{~h}$, followed by particle growth for $1 \mathrm{~h}$ at $1000^{\circ} \mathrm{C}$. A ferronickel concentrate with a nickel grade of $4 \%$ and a nickel recovery of $93.2 \%$ was achieved. In addition, the particle size increased with increasing temperature and duration time. Elliott [50] also studied the effects of varing coal, sulphur, pyrite, and sodium sulphate additions, and reduction temperatures in the range of $1000-1200^{\circ} \mathrm{C}$ on the selective reduction of a limonite and a saprolite. The resulted showed that the addition of sulphur into the limonite is more suitable for that into the saprolite. Results showed that increased carbon and sulphur addition and higher reduction temperature will lead to the formation of ferronickel alloys of decreasing nickel grade. For the sample limonite with sulphur addition of $4 \%$ at the reduction temperature of $1100^{\circ} \mathrm{C}$ for $1 \mathrm{~h}$, an average ferronickel particle size of $1.59 \mu \mathrm{m}$ was achieved, compared to $1.01 \mu \mathrm{m}$ for the same ore and reduction conditions without the addition of sulphur. While in the case of a saprolite, the addition of sulphur appeared to decrease the average ferronickel particle size. These researches therefore remind that in the process of optimizing selective reduction conditions, selection of the appropriate additives for different laterite ores is important. Scholars has lots of work for forming a system about the selection of the appropriate additives for different laterite ores

Many scholars found that $\mathrm{Na}_{2} \mathrm{SO}_{4}$ as an additive plays a significant role in the selective reduction of nickel laterite ores. $\mathrm{Li}$ et al. [51] found that $\mathrm{Na}_{2} \mathrm{SO}_{4}$ can enhance the reduction of nickel laterite by liberating iron and nickel from $\mathrm{Ni} / \mathrm{Fe}$-substituted lizardite and increase the size of ferronickel particles to significantly increase the content and recovery rate of nickel. Troilite generated in the reduction system serves as activating agent to accelerate melt phase formation, thereby facilitating the aggregation of ferronickel particles during the reduction and selectively enriching nickel by suppressing the complete metallisation of iron. Jiang et al. [47] thought that $\mathrm{Na}_{2} \mathrm{SO}_{4}$ could decompose to $\mathrm{Na}_{2} \mathrm{O}$ and $\mathrm{S}$ in a reducing atmosphere; and $\mathrm{Na}_{2} \mathrm{SO}_{4}$ was also reduced to $\mathrm{Na}_{2} \mathrm{~S}$. $\mathrm{S}$ and $\mathrm{Na}_{2} \mathrm{~S}$ were beneficial for selective reduction of $\mathrm{Ni}$ because of the formation of $\mathrm{FeS}$. Liu et al. [52] found that $\mathrm{Na}_{2} \mathrm{SO}_{4}$ reacted with $\mathrm{CO}$ and formed $\mathrm{Na}_{2} \mathrm{~S}$, which then reacts with $\mathrm{SiO}_{2}$ on the $\mathrm{FeO}$ surface to produce $\mathrm{FeS}$ and $\mathrm{Na}_{2} \mathrm{Si}_{2} \mathrm{O}_{5}$. Consequently, a thin film of $\mathrm{FeS}$ forms on the surface, hindering the contact 
between reducing gas and $\mathrm{FeO}$. Therefore, the reduction of iron is suppressed. With the addition of $\mathrm{Na}_{2} \mathrm{SO}_{4}$, the selective reduction of nickel laterite ores by $\mathrm{H}_{2}$ in a fluidised-bed reactor was studied by $\mathrm{Lu}$ et al.[53] . Results showed that $\mathrm{Na}_{2} \mathrm{SO}_{4}$ could overcome the kinetic problems faced by the laterite ore and show noticeable catalytic activity when the temperature reached over $750{ }^{\circ} \mathrm{C}$. It also showed that the reducting times affected the reduction process of the iron oxides. Rao et al. $[54,55]$ finished the study that the presence of $\mathrm{Na}_{2} \mathrm{SO}_{4}$ on selective reduction of a laterite ore from Indonesia. The results showed that the sulphur from $\mathrm{Na}_{2} \mathrm{SO}_{4}$ would react with iron in the laterite ore to form $\mathrm{Fe}-\mathrm{FeS}$ which can decrease the characteristic fusion temperature to promote the growth of ferronickel particles. In other word, $\mathrm{Na}_{2} \mathrm{SO}_{4}$ is of benefit to the selective reduction by decreasing iron metallisation ratio through sulfiding of iron oxides. Zhou et al. [56] conducted reduction of low-grade nickel laterite ore with the addition of $\mathrm{Na}_{2} \mathrm{~S}, \mathrm{Na}_{2} \mathrm{SO}_{4}$, and $\mathrm{CaSO}_{4}$. Comparing the three additives, $\mathrm{Na}_{2} \mathrm{SO}_{4}$ could promote the growth of ferronickel and improve the grade of nickel in ferronickel.

There were studies that showed $[57,58], \mathrm{CaO}$ is suitable as an additive to adjust the basicity of a saprolitic laterite ore during reduction-magnetic separation. The added $\mathrm{CaO}$ at proper dosage ranges would be conductive the growth of ferronickel particles. Shi et al. [59] found that $\mathrm{Na}_{2} \mathrm{~S}_{2} \mathrm{O}_{3}$ as an additive would act as an alkali salt as well as a vulcanizing agent, contributing to the efficient concentration of ferronickel. $\mathrm{Na}_{2} \mathrm{CO}_{3}$ is suitable as an additive to enhance the reduction and beneficiation of nickel by reacting with minerals of the nickel laterite ores to destroy ore structure [60].

In one word, the realization of selective reduction depends largely on two aspects, namely, controlling the reducing atmosphere which has a close correspondence with reductant type and dosage; and selecting appropriate additives. Suitable additives could strengthen selective reduction roasting, inhibit iron reduction, increasing the size of the ferronickel particles, and improve the subsequent magnetic separation effect. The growth of ferronickel particles in the reduction roasting stage is quite important for it determines whether the effective separation of ferronickel particles from impurities during subsequent magnetic separation stage could be achieved, which is dominated by reduction temperature, duration time as well as suitable additives. The selective reduction roasting of nickel and the growth of ferronickel decide the grade of nickel as well as the recovery rate of nickel together.

\section{Conclusion}

Overall, the hydrometallurgical processes enable valuable metals such as nickel, cobalt, iron, and magnesium to be recovered comprehensively. Their disadvantages are also obvious particularly high pressure leaching. The processes are long and complicated. The development of nitric/hydrochloric acid leaching in recent years especially that nitric acid leaching can be used widely would stimulate the application of hydrometallurgical processes for treating nickel laterite ores. While most of these above studies have achieved certain results in the laboratory stage only, and the actual application needs more work. The advantages of pyrometallurgical methods are simple in flow diagram. However, the advantage of high energy consumption is remarkable. This greatly limits the practical application of the pyrometallurgical methods. It is very important to research how to reduce the smelting temperature or to improve the utilization ratio of energy consumption. Reduction roasting-magnetic separation can be used to handle various types of laterite ores. There is no demand of high temperature for smelting. And the flow chat is simple then the hydrometallurgical processes. So it would be of the value for wide spreading on treating nickel laterite ores.

\section{Acknowledgments}

Authors are thankful to the finance support of the Doctoral Program Foundation of Institutions of Higher Education of China (No. 20130006110017) for this research.

\section{References}

[1] X. Ma, Z. Cui and B. Zhao, JOM 68, 3006-3014(2016). 
[2] J. Li, D. Xiong, H. Chen, R. Wang and Y. Liang, Hydrometallurgy 129, 14-18(2012).

[3] X. Lv, C. Bai, S. He and Q. Huang, ISIJ Int. 50, 380-385(2010).

[4] S. Pournaderi, E. Keskinkılıç, A. Geveci and Y.A. Topkaya, Can. Metall. Quart. 53, 26-37(2014).

[5] J. Kim, G. Dodbiba, H. Tanno, K. Okaya, S. Matsuo and T. Fujita, Miner. Eng. 23, 282-288(2010)

[6] C.A. Pickles, C.T. Harris, J. Peacey and J. Forster, Miner. Eng. 54, 52-62(2013).

[7] C.A. Pickles, J. Forster, and R. Elliott, Miner Eng. 65, 33-40(2014).

[8] S. Al-Khirbash, Ore Geol. Rev. 65, 199-212(2015).

[9] N.M. Rice, Miner. Eng. 88, 28-52(2016).

[10]T. Agacayak, V. Zedef and A. Aras, J. Cent. South Univ. 23, 39-43(2016).

[11]E.N. Zevgolis, C. Zografidis, T. Perraki and E. Devlin, J. Therm. Anal. Calorim. 100, 133-139(2010).

[12]A. Bunjaku, M. Kekkonen, K. Pietilä and P. Taskinen, Trans. Inst. Min. Metall. C. 121, 156-165(2012).

[13]C.A. Pickles and R. Elliott, Trans. Inst. Min. Metall. C. 124, 208-216(2015).

[14]R. Elliott, F. Rodrigues, C.A. Pickles and J. Peacey, Can. Metall. Quart. 54, 395-405(2015).

[15]K. Quast, J.N. Connor, W. Skinner, D.J. Robinson and J. Addai-Mensah, Miner. Eng. 79, 261-268(2015)

[16]S. Chen, X. Guo, W. Shi and D. Li, Journal of Central South University of Technology 17, 765-769(2010).

[17]M. Valix and W.H. Cheung, Miner. Eng. 15, 523-530(2002).

[18]B. Ma, C. Wang, W. Yang, F. Yin and Y. Chen, Miner. Eng. 50, 106-113(2013).

[19]M.A.R. Önal and Y.A. Topkaya, Hydrometallurgy 142, 98-107(2014).

[20]J.A. Johnson, R.G. McDonald, D.M. Muir and J. Tranne, Hydrometallurgy 78, 264-270(2005).

[21]D.H. Rubisov, J.M. Krowinkel and V.G. Papangelakis, Hydrometallurgy 58, 1-11(2000).

[22]K. Liu, Q. Chen, Z. Yin, H. Hu and Z. Ding, Hydrometallurgy 125, 125-136(2012).

[23]S. Yang, Nonferrous Met. (Extr. Metall). 1, 003(2013).

[24]C. Wang, F. Yin, Y. Chen, Y. Yang, B. Yang, W. Gao, Z. Wang, S. Yuan, J. Wang, N. Wang, D. Li and X. Jie, CN Patent No. 101,289,704 (22 October 2008).

[25]B. Ma, C. Wang, W. Yang, B. Yang and Y. Zhang, Miner. Eng. 45, 151-158(2013).

[26]B. Ma, W. Yang, B. Yang, C. Wang, Y. Chen and Y. Zhang, Hydrometallurgy 155, 88-94(2015).

[27]P. Zhang, Q. Guo, G. Wei, L. Meng, L. Han, J. Qu and T. Qi, Hydrometallurgy 157, 149-158(2015).

[28]J. MacCarthy, J. Addai-Mensah and A. Nosrati, Miner. Eng. 69, 154-164(2014).

[29]Q. Guo, J. Qu, B. Han, P. Zhang, Y. Song and T. Qi, Miner. Eng. 71, 1-6(2015).

[30]W. Astuti, T. Hirajima, K. Sasaki and N. Okibe, Miner. Metall. Proc. 32, 176-185(2015).

[31]B. Wang, Q. Guo, G. Wei, P. Zhang, J. Qu and T. Qi, Hydrometallurgy 129, 7-13(2012).

[32]N. Chen, Z. Cao, H. Zhong, F. Fan, P. Qiu and M. Wang, Metall. Res. Technol 112, 306(2015).

[33] S. Kursunoglu and M. Kaya, Int. J. Miner. Process. 150, 1-8(2016).

[34]J. MacCarthy, A. Nosrati, W. Skinner and J. Addai-Mensah, Hydrometallurgy 160, 26-37(2016).

[35]L. Meng, J. Qu, Q. Guo, K. Xie, P. Zhang, L. Han, G. Zhang and T. Qi, Sep. Purif. Technol. 143, 80-87(2015).

[36]F. Mccarthy and G. Brock, "Direct nickel process-breakthrough technology,"in Processing of Nickel Ores \& Concentrates '15 (Australian Minerals Research Centre, Karawara, Western Australia, 2015), pp. 1-10.

[37]W. Astuti, T. Hirajima, K. Sasaki and N. Okibe, Hydrometallurgy 161, 138-151(2016).

[38]S. Kursunoglu and M. Kaya, Int. J. Miner. Metall. Mater. 22, 1131-1140(2015).

[39]L. Sanping, W. Haibei, Z. Lei and Z. Xiaoping, Min. Metall. Eng. 97-99 (2014). (in Chinese) [40]A.E. Warner, C.M. Diaz, A.D. Dalvi, P.J. Mackey and A.V. Tarasov, JOM 58, 11-20(2006).

[41]B. Li, H. Wang and Y. Wei, Miner. Eng. 24, 1556-1562(2011). 
[42]E. Keskinkilic, S. Pournaderi, A. Geveci and Y.A. Topkaya, J. S. Afr. I. Min. Metall. 112, 877-882(2012).

[43]C. Cao, Z. Xue and H. Duan, Int. J. of Nonferrous Metall. 5, 9(2016).

[44]D. Gregurek, Z. Peng, C. Wenzl and J.F. White, JOM 68, 2998-2999(2016).

[45]P. Liu, B. Li, S.C. Cheung and W. Wu, Appl. Therm. Eng. 109, 542-559(2016).

[46]G. Zheng, D. Zhu, J. Pan, Q. Li, Y. An, J. Zhu and Z. Liu, J. Cent. South Univ. 21, 1771-1777(2014).

[47]M. Jiang, T. Sun, Z. Liu, J. Kou, N. Liu and S. Zhang, Int. J. Miner. Process. 123, 32-38(2013).

[48]X. Tang, R. Liu, L. Yao, Z. Ji, Y. Zhang and S. Li, International Journal of Minerals, Metallurgy, and Materials 21, 955-961(2014).

[49]D.Q. Zhu, Y. Cui, K. Vining, S. Hapugoda, J. Douglas, J. Pan and G.L. Zheng, Int. J. Miner. Process. 106, 1-7(2012).

[50]R. Elliott, "A Study on the Role of Sulphur in the Thermal Upgrading of Nickeliferous Laterite Ores," Ph.D. thesis, Queen's University, 2015.

[51]G. Li, T. Shi, M. Rao, T. Jiang and Y. Zhang, Miner. Eng. 32, 19-26(2012).

[52]Z. Liu, T. Sun, X. Wang and E. Gao, Int. J. Miner. Metall. Mater. 22, 901-906(2015).

[53]J. Lu, S. Liu, J. Shangguan, W. Du, F. Pan and S. Yang, Miner. Eng. 49, 154-164(2013).

[54]M. Rao, G. Li, X. Zhang, J. Luo, Z. Peng and T. Jiang, Sep. Sci. Technol. 51, 1408-1420(2016).

[55]M. Rao, G. Li, X. Zhang, J. Luo, Z. Peng and T. Jiang, Sep. Sci. Technol. 51, 1727-1735(2016).

[56]S. Zhou, B. Li, Y. Wei, H. Wang, C. Wang and B. Ma, "Effect of Additives on Phase Transformation of Nickel Laterite Ore During Low - Temperature Reduction Roasting Process Using Carbon Monoxide," in Drying, Roasting, and Calcining of Minerals, edited by P. B. Thomas et al. (TMS, 2015), pp. 177-184.

[57]G. Li, J. Luo, Z. Peng, Y. Zhang, M. Rao and T. Jiang, ISIJ Int. 55, 1828-1833(2015).

[58]Z. Liu, T. Sun, M. Jiang and E. Gao, Genetika 13, 1933-1944(2015).

[59]P. Shi, W. Du, S. Yang, S. Liu and J. Shangguan, J. Taiyuan Uni. of Tech. 47, 144-149(2016).

[60]G.H. Li, M.J. Rao, J. Tao, T.M. Shi and Q.Q. Huang, Chin. J. Nonferrous Metal 22, 274-280(2012). 